\title{
Unusual increases in serum lactate dehydrogenase isoenzyme- 5 activity caused by severe congestive cardiac failure: two case reports
}

\author{
V. PRABHAKARAN AND A. R. HENDERSON \\ From the Department of Clinical Biochemistry, University Hospital (University of Western Ontario), \\ London, Ontario N6A 5A5, Canada
}

SUMmaRY Two cases of congestive cardiac failure had unusually high activities of serum lactate dehydrogenase and lactate dehydrogenase isoenzyme-5. Values for isoenzyme-5 exceeding $87 \%$ of the total serum activity, and increases of 228- to 380-fold of the upper reference limit, are very uncommon.

Serum lactate dehydrogenase [EC 1.1.1.27] isoenzyme-5 (LD-5) appears to be a sensitive indicator of hepatocyte damage and elevations of this isoenzyme are commonly seen after liver hypoxia, a common sequel of congestive cardiac failure. This case report documents enzyme changes, much higher than those usually recorded, in two patients who died in heart failure.

\section{First case history}

A 53-year-old man was transferred from another hospital to University Hospital on 13 March 1975 with a history of worsening congestive cardiac failure with tachyarrhythmia, presumably secondary to an influenza-like illness that had started eight weeks previously. He was a carpenter with no history of exposure to hepatotoxins. His initial hospital admission had been on 24 February 1975.

\section{PHYSICAL EXAMINATION AND RELEVANT}

INITIAL LABORATORY FINDINGS

On admission the patient was noted to have laboured breathing and was receiving oxygen by face mask. He was oedematous with prominent jugular veins associated with an enlarged liver. Blood pressure was $80 / 60 \mathrm{~mm} \mathrm{Hg}$. A chest $x$-ray showed cardiomegaly and probable bilateral pulmonary oedema. Emergency cardiac catheterisation revealed gross enlargement of the cardiac chambers with minimal coronary artery disease. Lung scanning confirmed this finding. Isotopic venograms were suggestive of bilateral venous thrombosis in both legs. He had a marked

Received for publication 23 June 1978 acidosis (pH 7.25, or blood hydrogen ion $54 \mathrm{nmol} / \mathrm{l})$ with blood urea nitrogen $47 \mathrm{mg} / \mathrm{dl}$ (urea $17 \mathrm{mmol} / \mathrm{l}$ ), serum creatinine $4.2 \mathrm{mg} / \mathrm{dl}(371 \mu \mathrm{mol} / \mathrm{l})$, serum bilirubin $3.0 \mathrm{mg} / \mathrm{dl}(51.3 \mu \mathrm{mol} / \mathrm{l})$, serum urate 16.4 $\mathrm{mg} / \mathrm{dl}(975 \mu \mathrm{mol} / \mathrm{l})$, serum inorganic phosphorus $11.7 \mathrm{mg} / \mathrm{dl}(3.8 \mathrm{mmol} / \mathrm{l})$, serum calcium $6.7 \mathrm{mg} / \mathrm{dl}$ $(1.68 \mathrm{mmol} / \mathrm{l})$, and serum albumin $2.8 \mathrm{~g} / \mathrm{dl}(28 \mathrm{~g} / \mathrm{l})$. Activities of serum enzymes were markedly abnormal and are shown in the Table. The LD isoenzyme tracing is shown in the Figure.

The admission diagnosis was acute viral myocarditis.

\section{TREATMENT AND SUBSEQUENT COURSE}

The patient was found to be markedly oliguric (2-10 $\mathrm{ml}$ urine/ $\mathrm{h}$ ), and peritoneal dialysis and then plasmaphoresis were started to reduce the plasma volume.

Table Serum enzyme results (expressed as times the upper reference limits, except as noted)

\begin{tabular}{|c|c|c|c|}
\hline & \multicolumn{2}{|l|}{ Case 1} & \multirow{2}{*}{$\frac{\text { Case 2 }}{15 \text { Oct }}$} \\
\hline & $\begin{array}{l}13 \mathrm{Mar} \\
1975\end{array}$ & $\begin{array}{l}14 \text { Mar } \\
1975\end{array}$ & \\
\hline $\begin{array}{l}\text { Aspartate aminotransferase } \\
\text { [EC 2.6.1.1] }\end{array}$ & 156 & 171 & 199 \\
\hline $\begin{array}{l}\text { Alanine aminotransferase } \\
\text { [EC 2.6.1.2] }\end{array}$ & 73 & 88 & 56 \\
\hline $\begin{array}{l}\text { Aspartate/alanine amino- } \\
\text { transferase ratio }\end{array}$ & $2 \cdot 1$ & 1.9 & $3 \cdot 6$ \\
\hline Creatine kinase [EC 2.7.3.2] & 4 & 6 & 1.5 \\
\hline $\begin{array}{l}\text { Lactate dehydrogenase } \\
\text { [EC 1.1.1.27] }\end{array}$ & 40 & 49 & 39 \\
\hline LD-5 & 295 & 380 & 228 \\
\hline LD-5 ( $\%$ of total activity) & 87 & 91 & 94 \\
\hline
\end{tabular}

Reference limits are those currently in use at University Hospital London, Canada. 


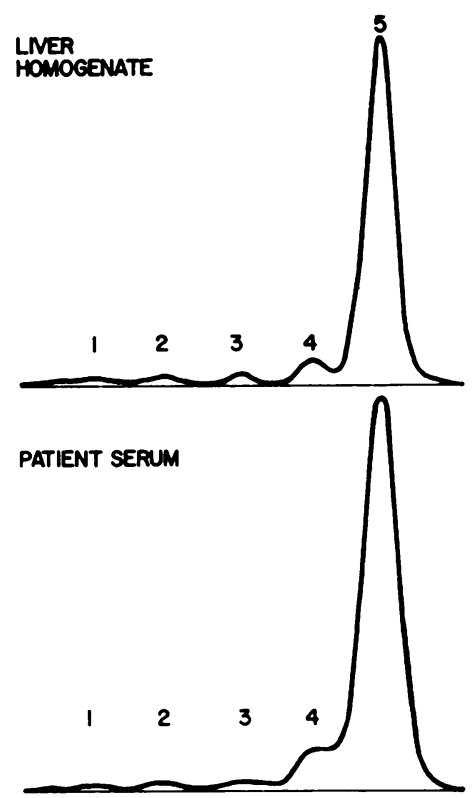

Figure $L D$ isoenzyme patterns of a liver homogenate and the serum of case 1. Patterns were obtained by agarose thin-film electrophoresis, and activities were applied that do not cause substrate depletion during the detection reaction.

Despite an earlier improvement after the administration of oxygen the respiratory distress became marked by the morning of 15 March 1975 . Oxygen $(100 \%)$ was given by nasotracheal tube, but eventually the patient had to be placed on a respirator. The congestive failure increased. He died in irreversible cardiogenic shock on the morning of 16 March 1975.

NECROPSY REPORT (relevant features)

Immediate cause of death: cardiogenic shock.

Heart: Weight $550 \mathrm{~g}$ (normal 250-350 g). Flabby consistency. Microscopic examination revealed recent muscle fibre death with large areas of fatty fibrosis.

Liver: Weight $2200 \mathrm{~g}$ (normal $1500-1800 \mathrm{~g}$ ). Soft consistency with nutmeg surface. Microscopy showed centrilobular necrosis with extension into the midzonal areas. The necrosis was principally congestive in origin. There was no evidence of interstitial fibrosis, partial fibrosis or piece-meal necrosis. No inflammatory cells were seen. Staining for Australian surface antigen (Shikata et al., 1974) was negative.

It was concluded that the findings were consistent with a viral myocarditis (of unknown viral origin despite an extensive search for viral antibodies), with liver changes due to the severe congestive cardiac failure and to anoxia.

\section{Second case history}

A 63-year-old woman was transferred on 15 October 1976 to University Hospital from another hospital where she had been admitted that morning in shock. Before collapse she had complained of intermittent retrosternal pain of about three weeks' duration. She was a known hypertensive and had been treated with diuretics since 1963 . She had a history of recurrent renal stones (which did not require surgery), and a cholecystectomy had previously been carried out for chronic cholecystitis and cholelithiasis.

\section{PHYSICAL EXAMINATION AND RELEVANT LABORATORY FINDINGS}

Before admission to University Hospital she had been treated with intravenous metaraminol. On admission the pulse was $130 / \mathrm{min}$ and the systolic blood pressure varied between 90 and $70 \mathrm{~mm} \mathrm{Hg}$. The diastolic pressure could not be measured. When the blood pressure dropped, she developed tonic generalised seizures. The extremities were pale and cool, and she was thought to be dehydrated. The metaraminol drip was stopped and saline infusions were started. A Swan-Ganz catheter was inserted. The chest radiograph showed cardiomegaly with clear lung fields. The electrocardiogram showed an abnormal, but non-specific, pattern.

She had a moderate hypoxaemia $\left(\mathrm{Po}_{2} 54 \mathrm{~mm} \mathrm{Hg}\right.$; $7.2 \mathrm{kPa}$ ) and normal blood $\mathrm{pH}$ and electrolytes. Activities of serum enzymes are shown in the Table. The blood white cell count was $17.6 \times 10^{9} / 1$ with $85 \%$ neutrophils. The urine contained large numbers of white and red cells, bacteria, and protein $(2+)$.

The admission diagnosis was cardiogenic and/or endotoxic (septic) shock.

\section{SUBSEQUENT COURSE}

The seizures during hypotensive episodes continued and were treated with a slow intravenous injection of diphenylhydantoin. While a second injection was being given the patient had a cardiac arrest and did not respond to resuscitation.

NECROPSY REPORT (relevant findings)

Immediate cause of death: cardiac asystole.

Heart: 1-day-old subendocardial infarction in left ventricle.

Liver: There was a hard nodule (anaplastic tumour cells) in the bed of the absent gall-bladder. Adjacent to it, in the liver, was a single small anaplastic nodule. The liver showed chronic passive hyperaemia with some centrilobular necrosis.

One parathyroid gland contained a carcinoma. Secondaries were discovered in a thoracic vertebral body and in the bed of the gall-bladder, and adjacent 
to it was a single small nodule in the liver.

It was concluded that the liver pathology was consistent with acute congestive cardiac failure. A diagnosis of primary hyperparathyroidism due to carcinoma of the parathyroid gland was also suggested.

\section{Discussion}

In case 1 there are two possible diagnoses. Apart from acute hepatic congestion, the possibility of viral hepatitis must be considered as a cause of the raised serum LD-5 activity. The histological features of viral hepatitis are well known (Edmondson and Peters, 1977) and they were entirely absent in all liver sections examined. In addition, staining for Australian surface antigen (Shikata et al., 1974) was negative. Therefore, viral hepatitis can be ruled out.

No serological evidence was obtained for the suspected viral cause of the cardiomyopathy. But this is very often difficult to obtain because of the large number of potentially infective viruses and the fact that the initial stage of viraemia may have passed by the time any cardiac lesion becomes apparent (British Medical Journal, 1977). One-third of 50 consecutive cases studied during a recent influenza $\mathbf{A}$ epidemic showed electrocardiographic changes (Verel et al., 1976). Therefore, the severe congestive cardiac failure after an influenza-like illness was probably due to a viral cardiomyocarditis for which there was some histological evidence. The increase in serum creatine kinase activity would also have been expected (Table).

Severe circulatory disturbances can also cause characteristic patterns of increased serum aminotransferase activities. Thus, the aspartate aminotransferase activity is very high (Table), and the aspartate: alanine aminotransferase ratio is around 2 (Wallerstedt et al., 1974). The increased serum LD-5 activity is in keeping with the predominant hepatic, rather than skeletal, muscle disorder.

In case 2 , consideration must be given to secondary metastatic infiltration of the liver as a cause for the increased serum LD-5 activity. Pathological examination showed only one small nodule, and as in general the frequency of serum lactate dehydrogenase abnormalities tends to be proportional to the severity of the lesion (Zondag and Klein, 1968), it seems unlikely that this single metastasis was the cause of the serum abnormality. Moreover, the degree of increase of serum LD-5 activity in hepatic metastasis is only about 10 times the upper reference limit (Nathan et al., 1973), which is much less than the increase encountered in case 2 (Table). Therefore, although metastatic infiltration of the liver seems unlikely as a cause of the increased serum LD-5 activity, the hepatic paraneoplastic syndrome must also be considered. In our experience in one case (Henderson and Grace, 1976) only modest increases of serum LD-5 activity are seen. Otherwise, we have been unable to find reference to LD isoenzyme elevations in this syndrome. It therefore seems likely that acute congestive cardiac failure is the major cause of increased activity of serum LD-5. This diagnosis tends to be suggested by the aminotransferase ratio and the extent of the elevation of aspartate aminotransferase activity (Wallerstedt $e t$ al., 1974). The slight increase of serum creatine kinase activity is in keeping with a 1-day-old subendocardial infarction.

Usually only modest increases of serum LD-5 activity occur in congestive cardiac failure (Batsakis and Briere, 1967; Dunn et al., 1973). We described one case where serum LD-5 was $72 \%$ of total serum LD activity (Henderson et al., 1973). Zondag (1967) described a case with serum enzyme activities of 60 fold and 290-fold the upper reference limits for LD and aspartate aminotransferase respectively. The LD-5 activity was $75.3 \%$ of the total serum LD activity. Nathan et al. (1973) described 11 cases of congestive cardiac failure with a mean increase of 17-fold their upper reference limit for serum LD-5 activity and a maximum increase of about 70 -fold. In our cases, increases of 228- to 380-fold were obtained (Table) with an LD isoenzyme pattern similar to that obtained from homogenised liver (Figure). In terms of percentage of the total serum LD activity, LD-5 accounted for up to $94 \%$, and this is comparable with the highest values reported for the LD-5 content of liver (Roman, 1969; Wilkinson, 1970) and with our own value of $84 \%$. Our assays have no anodic isoenzyme bias (McKenzie et al., 1976), and substrate depletion over the LD-5 band did not occur (McKenzie and Henderson, 1974).

Both cases strikingly illustrate the damaging effects on the liver of severe congestive cardiac failure, although the effects were aggravated by the use of metaraminol in case 2. This drug has an effect similar to that of noradrenaline in that it reduces splanchnic blood flow (Innes and Nickerson, 1975), thus further increasing the pre-existing hepatic anoxia. The examples quoted above and this case report illustrate the very wide variability in hepatic response to anoxia.

This work was supported by a grant (3-4, 1977-1978) from the Ontario Heart Foundation, which is gratefully acknowledged.

\section{References}

Batsakis, J. G., and Briere, R. O. (1967). Interpretive Enzymology, p. 54. C. C. Thomas, Springfield, Illinois. 
British Medical Journal (1977). Leading article. Viruses and cardiomyopathy. British Medical Journal, 2, 850.

Dunn, G. D., Hayes, P., Breen, K. J., and Schenker, S. (1973). The liver in congestive heart failure: a review. American Journal of the Medical Sciences, 265, 174-189.

Edmondson, H. A., and Peters, R. L. (1977). Liver. In Pathology, 7th edition, edited by W. A. D. Anderson and J. M. Kissane. Chapter 31, Volume 2, pp. 13211438. Mosby, St. Louis.

Henderson, A. R., and Grace, D. M. (1976). Liver originating isoenzymes of alkaline phosphatase in the serum: a paraneoplastic manifestation of a malignant schwannoma of the sciatic nerve. Journal of Clinical Pathology, 29, 237-240.

Henderson, A. R., Kostuk, W. J., and Griffiths, J. C. (1973). Increased lactate dehydrogenase isoenzyme-5 $\left(L_{5}\right)$ activity evidently caused by persistent diaphragmatic pressure on a congested liver. Clinical Chemistry, 19, 1300-1301.

Innes, I. R., and Nickerson, M. (1975). Norepinephrine, epinephrine, and the sympathomimetic amines. In The Pharmacological Basis of Therapeutics, 5th edition, edited by L. S. Goodman and A. Gilman. Chapter 24, pp. 477-513. Macmillan, New York.

McKenzie, D., Clark, P. I., and Henderson, A. R. (1976). How accurate are lactate dehydrogenase isoenzyme estimations by the thin-layer agarose fluorescent technique? Clinical Chemistry, 22, 1995-1998.

McKenzie, D., and Henderson, A. R. (1974). The effect of dilution and substrate repletion on the LDH isoenzyme distribution of sera with high LDH activities. Clinica Chimica Acta, 50, 147-150.

Nathan, L. E., Jr., Feldbruegge, D., and Westgard, J. O.
(1973). Applications of an automated determination of isoenzyme-5 of lactate dehydrogenase to the diagnosis of hepatic disease. Clinical Chemistry, 19, 1036-1039.

Roman, W. (1969). Quantitative estimation of lactate dehydrogenase isoenzymes in serum. I. Review of methods and distribution in human tissues. Enzymologia, 36, 189-219.

Shikata, T., Uzawa, T., Yoshiwara, N., Akatsuka, T., and Yamazaki, S. (1974). Staining method of Australia antigen in paraffin sections. Japanese Journal of Experimental Medicine, 44, 25-36.

Verel, D., Warrack. A. J. N., Potter, C. W., Ward, C., and Rickards, D. F. (1976). Observations on the A2 England influenza epidemic. American Heart Journal, 92, 290-296.

Wallerstedt, S., Olsson, R., and Waldenström, J. (1974). The diagnostic significance of a high ASAT/ALAT (GOT/GPT) ratio in patients with very high serum aminotransferase levels. Acta Medica Scandinavica, 195, 227-229.

Wilkinson, J. H. (1970). Isoenzymes, 2nd edition, pp. 136137. Chapman and Hall, London.

Zondag, H. A. (1967). Determination and Diagnostic Significance of Lactate Dehydrogenase Isoenzymes, p. 65. Van Gorcum, Assen, Netherlands.

Zondag, H. A., and Klein, F. (1968). Clinical applications of lactate dehydrogenase isozymes: alterations in malignancy. Annals of the New York Academy of Science, 151, 578-586.

Requests for reprints to: Dr A. R. Henderson, University Hospital, PO Box 5339, Postal Stn A, London, Ontario N6A 5A5, Canada. 